\title{
Effects of interface state charges on the electrical properties of $\mathrm{Si} / \mathrm{SiC}$ heterojunctions
}

Jianbo Liang, S. Nishida, T. Hayashi, M. Arai and Naoteru Shigekawa

\begin{tabular}{|c|l|}
\hline Citation & Applied Physics Letters, 105(15): 151607 \\
\hline Issue Date & $2014-10$ \\
\hline Type & Journal Article \\
\hline Textversion & Publisher \\
\hline Rights & $\begin{array}{l}\text { This article may be downloaded for personal use only. Any other use requires } \\
\text { prior permission of the author and AIP Publishing. } \\
\text { The following article appeared in Applied Physics Letters 105, 151607 (2014) and } \\
\text { may be found at http://doi.org/10.1063/1.4898674 } .\end{array}$ \\
\hline DOI & $10.1063 / 1.4898674$ \\
\hline
\end{tabular}

\author{
Self-Archiving by Author(s) \\ Placed on: Osaka City University Repository
}




\section{Effects of interface state charges on the electrical properties of $\mathrm{Si} / \mathrm{SiC}$ heterojunctions}

J. Liang, S. Nishida, T. Hayashi, M. Arai, and N. Shigekawa

Citation: Appl. Phys. Lett. 105, 151607 (2014); doi: 10.1063/1.4898674

View online: $\mathrm{http}: / / \mathrm{dx}$.doi.org/10.1063/1.4898674

View Table of Contents: http://aip.scitation.org/toc/apl/105/15

Published by the American Institute of Physics

\section{Articles you may be interested in}

Effects of thermal annealing process on the electrical properties of $\mathrm{p}^{+}-\mathrm{Si} / \mathrm{n}-\mathrm{SiC}$ heterojunctions

Applied Physics Letters 104, 161604 (2014); 10.1063/1.4873113

Electrical properties of $\mathrm{Si} / \mathrm{Si}$ interfaces by using surface-activated bonding

Journal of Applied Physics 114, 183703 (2013); 10.1063/1.4829676

Characterization and modeling of $n-n \mathrm{Si} / \mathrm{Si} C$ heterojunction diodes

Journal of Applied Physics 102, 014505 (2007); 10.1063/1.2752148

Improved electrical properties of $\mathrm{n}-\mathrm{n}$ and $\mathrm{p}-\mathrm{n} \mathrm{Si} / \mathrm{SiC}$ junctions with thermal annealing treatment Journal of Applied Physics 120, 034504 (2016); 10.1063/1.4959072

Fast atom beam-activated n-Si/n-GaAs wafer bonding with high interfacial transparency and electrical conductivity

Journal of Applied Physics 113, 203512 (2013); 10.1063/1.4807905

Electrical transport properties of wafer-fused $p-\mathrm{GaAs} / n-\mathrm{GaN}$ heterojunctions

Applied Physics Letters 93, 112103 (2008); 10.1063/1.2983648

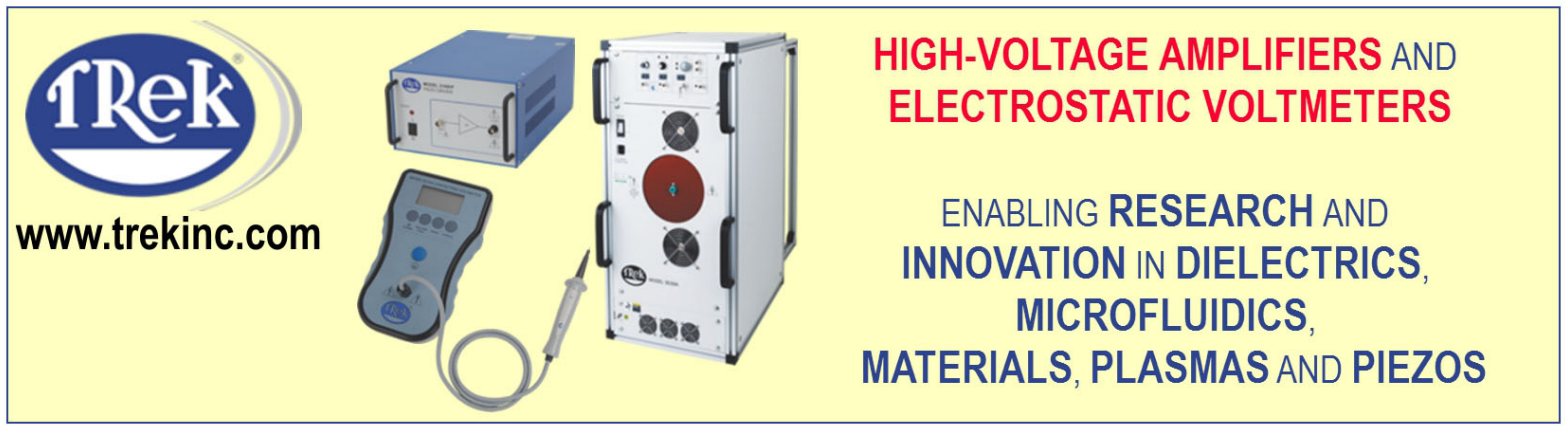




\title{
Effects of interface state charges on the electrical properties of Si/SiC heterojunctions
}

\author{
J. Liang, ${ }^{1, a)}$ S. Nishida, ${ }^{1}$ T. Hayashi, ${ }^{1}$ M. Arai,${ }^{2}$ and N. Shigekawa ${ }^{1}$ \\ ${ }^{1}$ Department of Electrical Engineering, Osaka City University, Sugimoto 3-3-138, Sumiyoshi, \\ Osaka 558-8585, Japan \\ ${ }^{2}$ New Japan Radio Co., Ltd., Fukuoka 2-1-1, Fujimino, Saitama 356-8510, Japan
}

(Received 22 July 2014; accepted 6 October 2014; published online 17 October 2014)

\begin{abstract}
Electrical properties of $\mathrm{p}^{-}-\mathrm{Si} / \mathrm{n}^{-}-\mathrm{SiC}, \mathrm{p}-\mathrm{Si} / \mathrm{n}^{-}-\mathrm{SiC}, \mathrm{p}^{+}-\mathrm{Si} / \mathrm{n}^{-}-\mathrm{SiC}$, and $\mathrm{n}^{+}-\mathrm{Si} / \mathrm{n}^{-}-\mathrm{SiC}$ heterojunctions fabricated by using surface-activated bonding are investigated. Their flat-band voltages obtained from capacitance-voltage $(C-V)$ measurements are found to be $\sim 0.92 \mathrm{eV}$, which suggests that the Fermi level should be pinned at the bonding interface. An analysis by using the charge neutral level model reveals that the $C-V$ characteristics are sensitive to the density of interface states. The measured $C-V$ characteristics of $\mathrm{p}^{+}-\mathrm{Si} / \mathrm{n}^{-}-\mathrm{SiC}$ and $\mathrm{n}^{+}-\mathrm{Si} / \mathrm{n}^{-}-\mathrm{SiC}$ junctions are in quantitative agreement with modeled ones obtained for the interface states density and the conduction-band discontinuity of $2.3 \times 10^{13} \mathrm{~cm}^{-2} \mathrm{eV}^{-1}$ and $0.3 \mathrm{eV}$, respectively. (C) 2014 AIP Publishing $L L C$.

[http://dx.doi.org/10.1063/1.4898674]
\end{abstract}

Silicon carbide $(\mathrm{SiC})$ based devices are promising as the next generation power devices because of its unique physical properties such as a wide band gap, a high thermal conductivity, a high electron saturation velocity, the high physical and chemical stability, and a high breakdown field. ${ }^{1}$ The combination of $\mathrm{SiC}$ with $\mathrm{Si}$ technologies has potential application for bipolar transistors with wide band gap emitters, ${ }^{2,3}$ switching devices, ${ }^{4}$ electroluminescence devices, ${ }^{5}$ and sensors. ${ }^{6}$ In growing $\mathrm{SiC}$ layers on $\mathrm{Si}^{7}$ because of the large lattice mismatch and difference in thermal expansion coefficients between $\mathrm{Si}$ and $\mathrm{SiC}$, a marked residual stress and defects with high densities are frequently encountered, which limits the intrinsic performance of grown $\mathrm{Si} / \mathrm{SiC}$ heterojunctions. ${ }^{8}$

One way to overcome these difficulties is direct wafer bonding such as hydrophilic wafer bonding ${ }^{9}$ and surfaceactivated bonding $(\mathrm{SAB}) .{ }^{10}$ In $\mathrm{SAB}$, surfaces of substrates are activated by the fast atom beams of Ar prior to bonding, which enables us to bond substrates without heating them. ${ }^{10-13}$ However, interface states with high densities are likely to be formed in the SAB process since dangling bonds are unveiled on sample surfaces due to the irradiation of $\mathrm{Ar}$ atom beams. It was pointed out that such interface states modified potential barriers at the interface of $n-G a P / n-$ $\mathrm{InGaP}^{14}$ and $\mathrm{p}-\mathrm{GaAs} / \mathrm{n}-\mathrm{GaN}$ junctions. ${ }^{15,16}$ In $\mathrm{n}$-n and $\mathrm{p}-\mathrm{n}$ $\mathrm{Ge} / \mathrm{SiC}$ heterojunction diodes, the interface states caused the pinning of Fermi-level. ${ }^{17}$

Reported conduction band discontinuities in $\mathrm{Si} / \mathrm{SiC}$ heterojunctions are largely scattered between 0.21 and $1.9 \mathrm{eV}^{7,18}$ This suggests that the electrical properties of the $\mathrm{Si} / \mathrm{SiC}$ heterojunctions should be largely varied by the possible interface states. The impact of the interface states to the electrical properties of $\mathrm{Si} / \mathrm{SiC}$ junctions has not yet been fully understood.

In this letter, we report on the electrical properties of $\mathrm{Si} /$ $\mathrm{SiC}$ heterojunctions fabricated by using $\mathrm{SAB}$. We measured their current-voltage $(I-V)$ and capacitance-voltage $(C-V)$

${ }^{a}$ E-mail address: liang@elec.eng.osaka-cu.ac.jp characteristics. Furthermore, we analyzed the influence of charges in the interface states on the electrical characteristics of $\mathrm{p}^{+}-\mathrm{Si} / \mathrm{n}^{-}-\mathrm{SiC}$ and $\mathrm{n}^{+}-\mathrm{Si} / \mathrm{n}^{-}-\mathrm{SiC}$ junctions by using the charge neutral level (CNL) model. ${ }^{19}$

We used four types $\left(\mathrm{p}^{-}-, \mathrm{p}-, \mathrm{p}^{+}-\right.$, and $\mathrm{n}^{+}-$) of (100) $\mathrm{Si}$ substrates and $\mathrm{n}^{-}-4 \mathrm{H}-\mathrm{SiC}$ epitaxial substrate. Their carrier concentrations are shown in Table I. The carrier concentrations of Si substrates were estimated by Hall measurements at room temperature. $\mathrm{Al} / \mathrm{Ni} / \mathrm{Au}$ multilayers were evaporated on the backsides of $\mathrm{p}^{-}-$, $\mathrm{p}$ - and $\mathrm{p}^{+}-\mathrm{Si}$ substrates and $\mathrm{n}^{-}-\mathrm{SiC}$ epitaxial substrates, respectively. The ohmic contacts of $\mathrm{p}-$ type $\mathrm{Si}$ and $\mathrm{n}$-type $\mathrm{SiC}$ were formed by a rapid thermal annealing at 400 and $1000^{\circ} \mathrm{C}$ for $60 \mathrm{~s}$ in $\mathrm{N}_{2}$ gas ambient, respectively. Then, we bonded each of the p-type substrates to the $\mathrm{SiC}$ epitaxial substrates so that $\mathrm{p}^{-}-\mathrm{Si} / \mathrm{n}^{-}-\mathrm{SiC}, \mathrm{p}-\mathrm{Si} / \mathrm{n}^{-}-\mathrm{SiC}$, and $\mathrm{p}^{+}-\mathrm{Si} / \mathrm{n}^{-}-\mathrm{SiC}$ junctions were fabricated. $\mathrm{n}^{+}-\mathrm{Si} / \mathrm{n}^{-}-\mathrm{SiC}$ junctions were fabricated by evaporating $\mathrm{Ti} / \mathrm{Au}$ multilayers on the backsides of $n^{+}-S i$ substrates after the bonding. All of the four junctions were diced into $4 \mathrm{~mm}^{2}$ pieces. A Ni/n ${ }^{-}-\mathrm{SiC}$ Schottky diode was fabricated by deposition of $100 \mathrm{~nm}$ nickel film on the surfaces of $\mathrm{n}^{-}-\mathrm{SiC}$ substrates. Prior to Schottky contact deposition, the ohmic contacts of substrates were formed. Their $I-V$ and $C$ - $V$ characteristics were measured using an ADCMT 6242 Source Measurement Unit and an Agilent E4980A Precision Impedance Analyzer, respectively.

TABLE I. The carrier concentration and the thickness of substrates.

\begin{tabular}{lccc}
\hline \hline Type & Carrier concentration $\mathrm{cm}^{-3}$ & Thickness $\mu \mathrm{m}$ \\
\hline $\mathrm{p}^{-}-\mathrm{Si}$ & $1.39 \times 10^{15}$ & 525 \\
$\mathrm{p}-\mathrm{Si}$ & $2.43 \times 10^{17}$ & 525 \\
$\mathrm{p}^{+}-\mathrm{Si}$ & $2.64 \times 10^{19}$ & 525 \\
$\mathrm{n}^{+}-\mathrm{Si}$ & & $2.61 \times 10^{19}$ & 525 \\
$\mathrm{n}^{-}-4 \mathrm{H}-\mathrm{SiC}$ & Epitaxial layer & $\sim 5 \times 10^{15}$ & 2.8 \\
& Buffer layer & $\sim 1 \times 10^{18}$ & 0.5 \\
& Substrate & $\sim 1 \times 10^{19}$ & 235 \\
\hline \hline
\end{tabular}




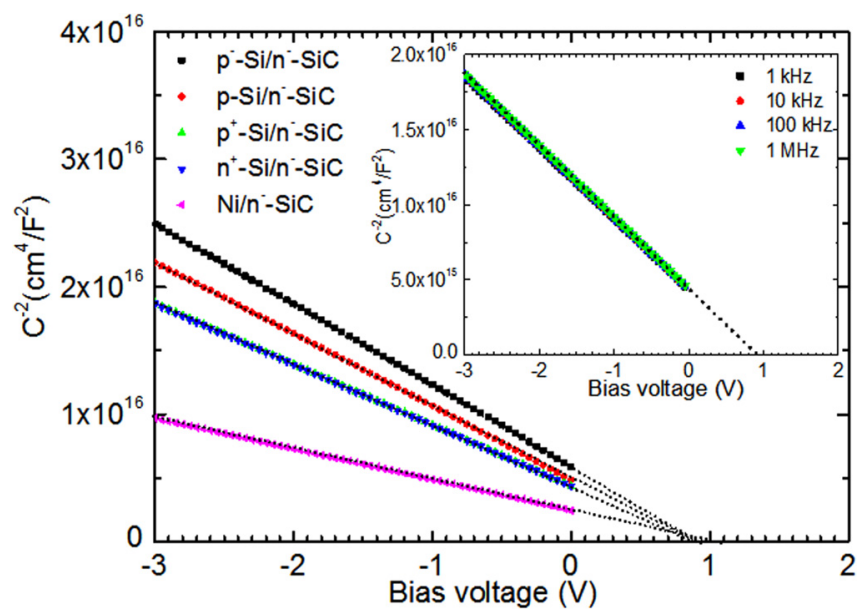

FIG. 1. $C-V$ characteristics of $\mathrm{p}^{-}-\mathrm{Si} / \mathrm{n}^{-}-\mathrm{SiC}, \mathrm{p}-\mathrm{Si} / \mathrm{n}^{-}-\mathrm{SiC}, \mathrm{p}^{+}-\mathrm{Si} / \mathrm{n}^{-}-\mathrm{SiC}, \mathrm{n}^{+}-$ $\mathrm{Si} / \mathrm{n}^{-}-\mathrm{SiC}$, and $\mathrm{Ni} / \mathrm{n}^{-}-\mathrm{SiC}$ junctions measured at room temperature. The inset shows $C-V$ characteristics of $\mathrm{p}^{+}-\mathrm{Si} / \mathrm{n}^{-}-\mathrm{SiC}$ junctions measured at room temperature and frequencies ranging from $1 \mathrm{kHz}$ to $1 \mathrm{MHz}$.

The $1 / C^{2}-V$ characteristics of $\mathrm{p}^{-}-\mathrm{Si} / \mathrm{n}^{-}-\mathrm{SiC}, \mathrm{p}-\mathrm{Si} / \mathrm{n}^{-}-\mathrm{SiC}$, $\mathrm{p}^{+}-\mathrm{Si} / \mathrm{n}^{-}-\mathrm{SiC}, \mathrm{n}^{+}-\mathrm{Si} / \mathrm{n}^{-}-\mathrm{SiC}$, and $\mathrm{Ni} / \mathrm{n}^{-}-\mathrm{SiC}$ junctions measured at room temperature and a frequency of $10 \mathrm{kHz}$ are shown in Fig. 1. The characteristics indicated a straight line and the flat band voltages were found to be $0.92,0.88,0.92$, and $0.92 \mathrm{~V}$ for $\mathrm{p}^{-}-\mathrm{Si} / \mathrm{n}^{-}-\mathrm{SiC}, \mathrm{p}-\mathrm{Si} / \mathrm{n}^{-}-\mathrm{SiC}, \mathrm{p}^{+}-\mathrm{Si} / \mathrm{n}^{-}-\mathrm{SiC}$, and $\mathrm{n}^{+}-\mathrm{Si} / \mathrm{n}^{-}-\mathrm{SiC}$ junctions, respectively, by linearly extrapolating $1 / C^{2}$ to zero. It is noteworthy that the flat band voltages are $\sim 0.9 \mathrm{~V}$, irrespective of the polarity and the doping concentrations of Si substrates. The estimated flat band voltage is markedly small in comparison with previous reports $(\sim 2 \mathrm{~V})$ for $\mathrm{n}-\mathrm{Si} / \mathrm{n}-\mathrm{SiC}^{7,20}$ and $\mathrm{p}-\mathrm{Si} / \mathrm{n}-\mathrm{SiC}^{9}$ heterojunctions. The inset shows the $1 / C^{2}-V$ characteristics of $\mathrm{p}^{+}-\mathrm{Si} / \mathrm{n}^{-}-\mathrm{SiC}$ junctions measured at room temperature and frequencies between $1 \mathrm{kHz}$ and $1 \mathrm{MHz}$. The frequency dispersion was not observed on the bias voltage between -3 and $0 \mathrm{~V}$. Similar to $\mathrm{p}^{+}-\mathrm{Si} / \mathrm{n}^{-}-\mathrm{SiC}$ junctions, the frequency dispersion was also not observed in $\mathrm{n}^{+}-\mathrm{Si} / \mathrm{n}^{-}-\mathrm{SiC}$ junctions (not shown in this figure). Using the slopes of $1 / C^{2}-V$ characteristics, the donor concentrations of the $\mathrm{n}^{-}$-SiC epitaxial layer were estimated to be $3.10 \times 10^{15}, 3.12 \times 10^{15}$, and $6.52 \times 10^{15} \mathrm{~cm}^{-3}$, for $\mathrm{p}^{+}-\mathrm{Si} / \mathrm{n}^{-}-\mathrm{SiC}, \mathrm{n}^{+}-\mathrm{Si} / \mathrm{n}^{-}-\mathrm{SiC}$, and $\mathrm{Ni} / \mathrm{n}^{-}-\mathrm{SiC}$ junctions, respectively.

The $I-V$ characteristics of $\mathrm{p}^{+}-\mathrm{Si} / \mathrm{n}^{-}-\mathrm{SiC}$ and $\mathrm{n}^{+}-\mathrm{Si} / \mathrm{n}^{-}$$\mathrm{SiC}$ junctions measured at various temperatures are shown in Figs. 2(a) and 2(b), respectively. The respective curves revealed rectifying properties similarly to those in conventional $p n$ junctions. The reverse-bias current increased with increasing the bias voltage and the temperature of the measurement in each junction. It is noteworthy that the $I-V$ characteristics of the two junctions at each temperature are similar to each other. The activation energy of the reversebias current at $-3 \mathrm{~V}$ was estimated to be 0.37 and $0.39 \mathrm{eV}$ for $\mathrm{p}^{+}-\mathrm{Si} / \mathrm{n}^{-}-\mathrm{SiC}$ and $\mathrm{n}^{+}-\mathrm{Si} / \mathrm{n}^{-}-\mathrm{SiC}$ junctions, respectively.

The flat-band voltage $V_{d}$ is expressed as

$$
\mathrm{q} V_{d}=E_{g p}+\Delta E_{c}-\delta_{n-s i c}-\delta_{p-s i}
$$

and

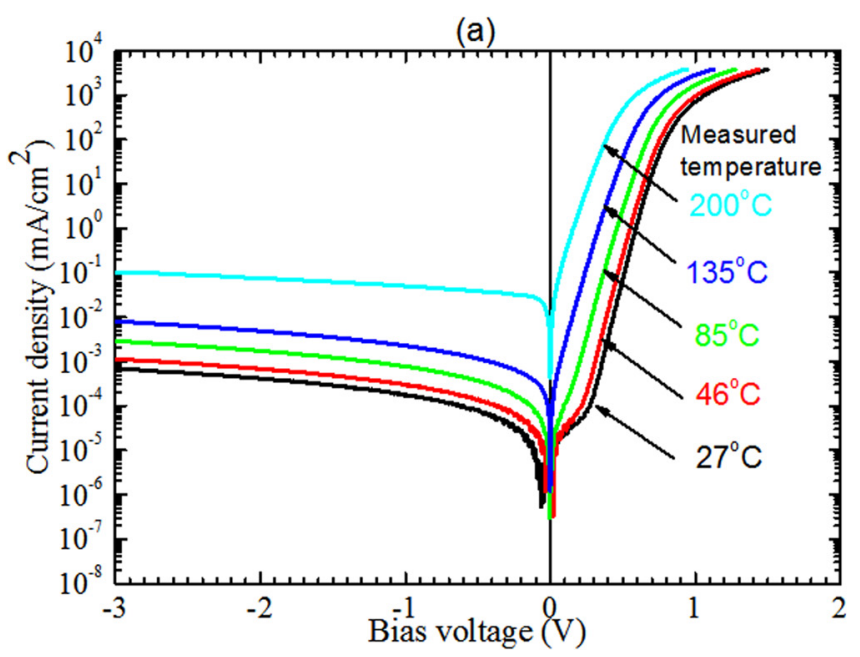

(b)

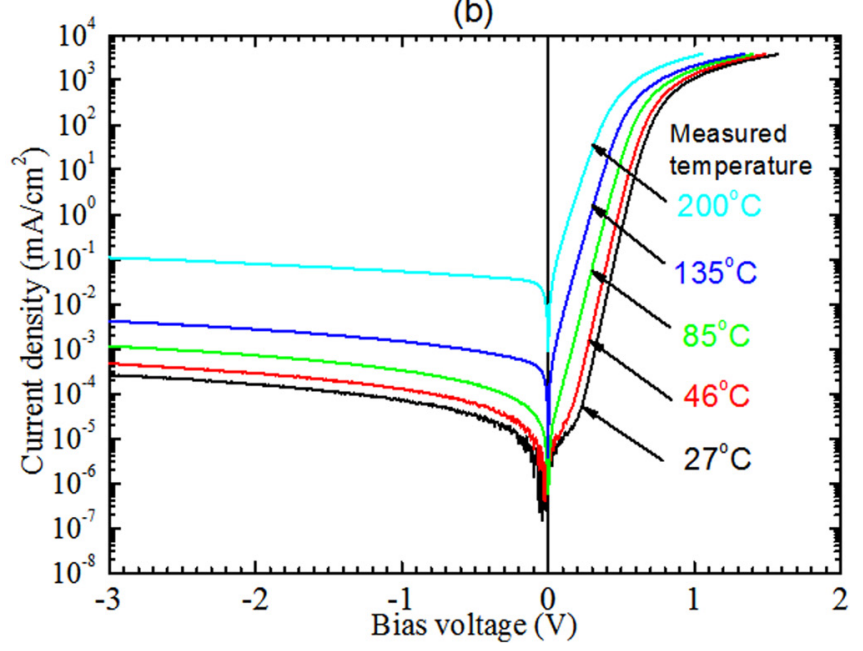

FIG. 2. Temperature dependence of the $I-V$ characteristics of (a) $\mathrm{p}^{+}-\mathrm{Si} / \mathrm{n}^{-}$ $\mathrm{SiC}$ junctions and (b) $\mathrm{n}^{+}-\mathrm{Si} / \mathrm{n}^{-}-\mathrm{SiC}$ junctions.

$$
\mathrm{q} V_{d}=\Delta E_{c}-\delta_{n-s i c}+\delta_{n-s i},
$$

for $\mathrm{p}^{+}-\mathrm{Si} / \mathrm{n}^{-}-\mathrm{SiC}$ and $\mathrm{n}^{+}-\mathrm{Si} / \mathrm{n}^{-}-\mathrm{SiC}$ junctions, respectively. Note that $q$ is the elementary charge, $E_{g p}$ is the energy gap of $\mathrm{p}^{+}-\mathrm{Si}, \Delta E_{c}$ is the conduction-band discontinuity, and $\delta_{p-s i}$, $\delta_{n-s i}$, and $\delta_{n \text {-sic }}$ refer to the position of the Fermi level relative to the valence-band maximum in $\mathrm{p}^{+}-\mathrm{Si}$, relative to the conduction-band minimum in $\mathrm{n}^{+}-\mathrm{Si}$ and relative to the conduction-band minimum in $\mathrm{n}^{-}-\mathrm{SiC}$, respectively. Here, we assumed that no electric charges are placed at the interface. From these expressions, $\Delta E_{c}$ was estimated to be 0.05 and $1.09 \mathrm{eV}$ for the $\mathrm{p}^{+}-\mathrm{Si} / \mathrm{n}^{-}-\mathrm{SiC}$ and $\mathrm{n}^{+}-\mathrm{Si} / \mathrm{n}^{-}-\mathrm{SiC}$ junctions, respectively. The disagreement in $\Delta E_{c}$ between the two junctions, which stems from the result that the flat band voltages of the junctions were close to each other, suggests that interface states with high densities are formed at the bonding interfaces and the Fermi level is pinned.

In analyzing the influence of the interface charges on the $C-V$ characteristics of $\mathrm{p}^{+}-\mathrm{Si} / \mathrm{n}^{-}-\mathrm{SiC}$ and $\mathrm{n}^{+}-\mathrm{Si} / \mathrm{n}^{-}-\mathrm{SiC}$ junctions, we assume the followings: (1) The interface states are uniformly distributed in the overlap of band gaps of $\mathrm{SiC}$ and Si layers. Their density $\left(D_{i t}\right)$ is, consequently, independent of their energy. (2) Carriers trapped in the interface states are in thermal equilibrium with those in Si layer, i.e., the Fermi level in the interface states coincides with that in Si layers 
irrespective of bias voltages. (3) The distribution of charges in Si layer is locally determined by solving Poisson's equation, and the distribution of charges in $\mathrm{SiC}$ layer is estimated by using the space charge in the depletion layer. (4) The sum of the sheet charge densities in the entire junctions is zero.

For $\mathrm{p}^{+}-\mathrm{Si} / \mathrm{n}^{-}-\mathrm{SiC}$ junctions, interface-state charge density $\left(Q_{i t}\right)$ can be defined as

$$
Q_{i t}=Q_{D i t}+Q_{A i t}=q D_{i t} \int_{0}^{E_{C N L}}\left(1-F_{i t}\right) d E-q D_{i t} \int_{E_{C N L}}^{E_{g p}} F_{i t} d E,
$$

where $Q_{D i t}$ and $Q_{A i t}$ are positive charge density in the donorlike states and negative charge density in the acceptor-like states, respectively. The energy of CNL $E_{C N L}$ is preset as $0.36 \mathrm{eV}^{21}$ above the valence band edge of Si. The state occupation function $F_{i t}$ is given by

$$
F_{i t}=\frac{1}{\exp \left(\left(E-E_{F P}\right) / k T\right)+1},
$$

where $E_{F P}$ is the Fermi level in $\mathrm{p}^{+}-\mathrm{Si}, k$ is the Boltzman constant, and $T$ is the temperature. Note that $Q_{i t}$ is determined when the surface potential in the $\mathrm{p}^{+}-\mathrm{Si}$ layer $\psi_{s}$ is given. The charge per unit area in the $\mathrm{p}^{+}-\mathrm{Si}$ layer $Q_{p-s i}$ is also obtained for a given $\psi_{s .}{ }^{21}$ Noting that the total charge per unit area must be equal to zero, the depletion layer thickness $W$ is expressed as

$$
W=\frac{-\left(Q_{p-s i}+Q_{i t}\right)}{q N_{n-s i c}},
$$

using the donor concentration $N_{n-s i c}$ of $\mathrm{n}^{-}$-SiC epitaxial layer which was obtained from the $C-V$ characteristics of $\mathrm{Ni} / \mathrm{n}^{-}$$\mathrm{SiC}$ junctions. Furthermore, the bias voltage is expressed using the above parameters (not shown). Thus, the relationship between capacitance and bias voltage is numerically calculated. The $C-V$ characteristics in the $\mathrm{n}^{+}-\mathrm{Si} / \mathrm{n}^{-}-\mathrm{SiC}$ junctions are obtained in similar manners.

The $1 / C^{2}-V$ characteristics obtained using a variety of $D_{i t}$ values ranging between $2.3 \times 10^{13}$ and $4.3 \times 10^{13} \mathrm{~cm}^{-2} \mathrm{eV}^{-1}$ with $\Delta E_{c}$ of $0.3 \mathrm{eV}$ are shown in Fig. 3(a). $1 / C^{2}$ in the $\mathrm{n}^{+}-\mathrm{Si} /$ $\mathrm{n}^{-}-\mathrm{SiC}$ junctions decreases as $D_{i t}$ increases. In the $\mathrm{p}^{+}-\mathrm{Si} / \mathrm{n}^{-}$ $\mathrm{SiC}$ junctions, in contrast, $1 / C^{2}$ increases as $D_{i t}$ increases. We find that $1 / C^{2}-V$ characteristics of the two junctions are close to each other for $D_{i t}$ of $2.3 \times 10^{13} \mathrm{~cm}^{-2} \mathrm{eV}^{-1}$. The $1 / C^{2}-V$ characteristics of the two junctions obtained for $D_{i t}$ of $2.3 \times 10^{13} \mathrm{~cm}^{-2} \mathrm{eV}^{-1}$ with a variety of $\Delta E_{c}$ are shown in Fig. $3(b)$. The flat band voltage of the two junctions is shifted in accordance with the change in $\Delta E_{c}$. The $1 / C^{2}-V$ characteristics are close to the measurements when $D_{i t}$ and $\Delta E_{c}$ are $2.3 \times 10^{13} \mathrm{~cm}^{-2} \mathrm{eV}^{-1}$ and $0.3 \mathrm{eV}$, respectively. The estimated $\Delta E_{c}$ is similar to a previous report for $\mathrm{Si} / \mathrm{SiC}$ junctions ${ }^{20}$ that were fabricated by plasma-enhanced chemical vapordeposition. We find that the obtained $D_{i t}$ is much larger than a previously reported one for $\mathrm{Si} / \mathrm{SiC}$ heterojunctions fabricated by direct wafer bonding. ${ }^{22}$ In spite of such large $D_{i t}$ values, the result that frequency dispersions were negligible in the $C-V$ characteristics of $\mathrm{p}^{+}-\mathrm{Si} / \mathrm{n}^{-}-\mathrm{SiC}$ junctions [see the inset of Fig. 1] suggests that $\mathrm{SAB}$-based $\mathrm{Si} / \mathrm{SiC}$ junctions with
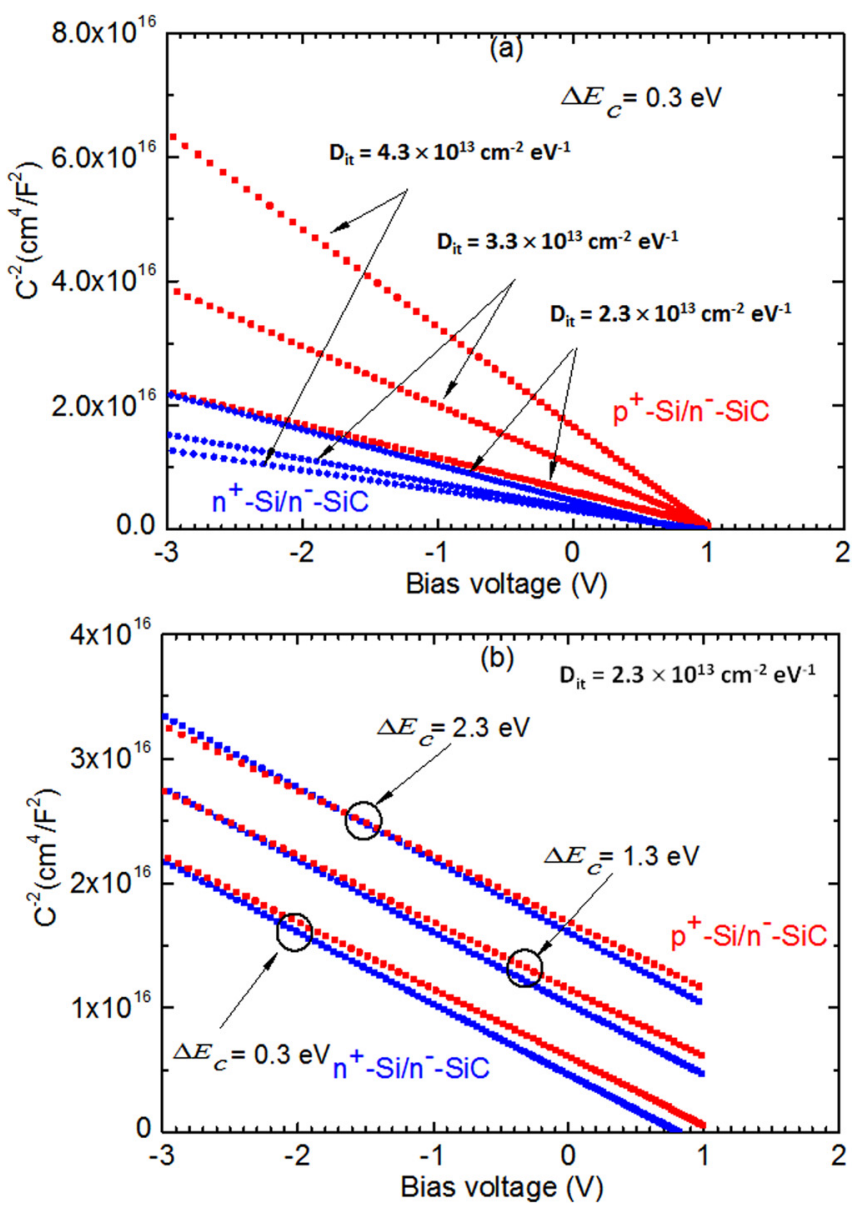

FIG. 3. The calculated $C-V$ characteristics of $\mathrm{p}^{+}-\mathrm{Si} / \mathrm{n}^{-}-\mathrm{SiC}$ and $\mathrm{n}^{+}-\mathrm{Si} / \mathrm{n}^{-}-$ $\mathrm{SiC}$ junctions with different (a) $D_{i t}$ and (b) $\Delta E_{c}$ values.

heavily-doped Si layers might be applicable for novel devices. Given that the amorphous layer at the bonding interface induces $D_{i t}$, it should be reduced by thinning the amorphous layer. According to our previous report, ${ }^{10}$ the amorphous layer becomes thin with increasing the annealing temperature and finally vanishes after annealing at $1000^{\circ} \mathrm{C}$.

Based on these estimations, the energy-band diagrams for $\mathrm{p}^{+}-\mathrm{Si} / \mathrm{n}^{-}-\mathrm{SiC}$ and $\mathrm{n}^{+}-\mathrm{Si} / \mathrm{n}^{-}-\mathrm{SiC}$ junctions are depicted. The band diagrams at bias voltages of 0 and $-3 \mathrm{~V}$ of the respective junctions are shown in Figs. 4(a) and 4(b). We find by comparing the two figures that the band profiles in the $\mathrm{SiC}$ layers of the respective junctions are similar to each other. Consequently, the results of the $I-V$ measurements that (1) the entire $I-V$ characteristics of the $\mathrm{p}^{+}-\mathrm{Si} / \mathrm{n}^{-}-\mathrm{SiC}$ and $\mathrm{n}^{+}$$\mathrm{Si} / \mathrm{n}^{-}-\mathrm{SiC}$ junctions are close to each other irrespective of the ambient temperatures and (2) the activation energy of the reverse-bias current is close to each other $(0.37$ and $0.39 \mathrm{eV}$ at $-3 \mathrm{~V}$ for the $\mathrm{p}^{+}-\mathrm{Si} / \mathrm{n}^{-}-\mathrm{SiC}$ and $\mathrm{n}^{+}-\mathrm{Si} / \mathrm{n}^{-}-\mathrm{SiC}$ junctions, respectively) suggest that the reverse-bias current occurs due to (1) the thermal excitation of electrons from the valenceband (conduction-band) edges in the $\mathrm{p}^{+}-\mathrm{Si}\left(\mathrm{n}^{+}-\mathrm{Si}\right)$ layers of the respective junctions and (2) the subsequent tunneling process across the $\mathrm{SiC}$ depletion layer.

In summary, we fabricated $\mathrm{p}^{-}-\mathrm{Si} / \mathrm{n}^{-}-\mathrm{SiC}, \mathrm{p}-\mathrm{Si} / \mathrm{n}^{-}-\mathrm{SiC}$, $\mathrm{p}^{+}-\mathrm{Si} / \mathrm{n}^{-}-\mathrm{SiC}$, and $\mathrm{n}^{+}-\mathrm{Si} / \mathrm{n}^{-}-\mathrm{SiC}$ junctions using surface activated bonding and measured their electrical properties at 

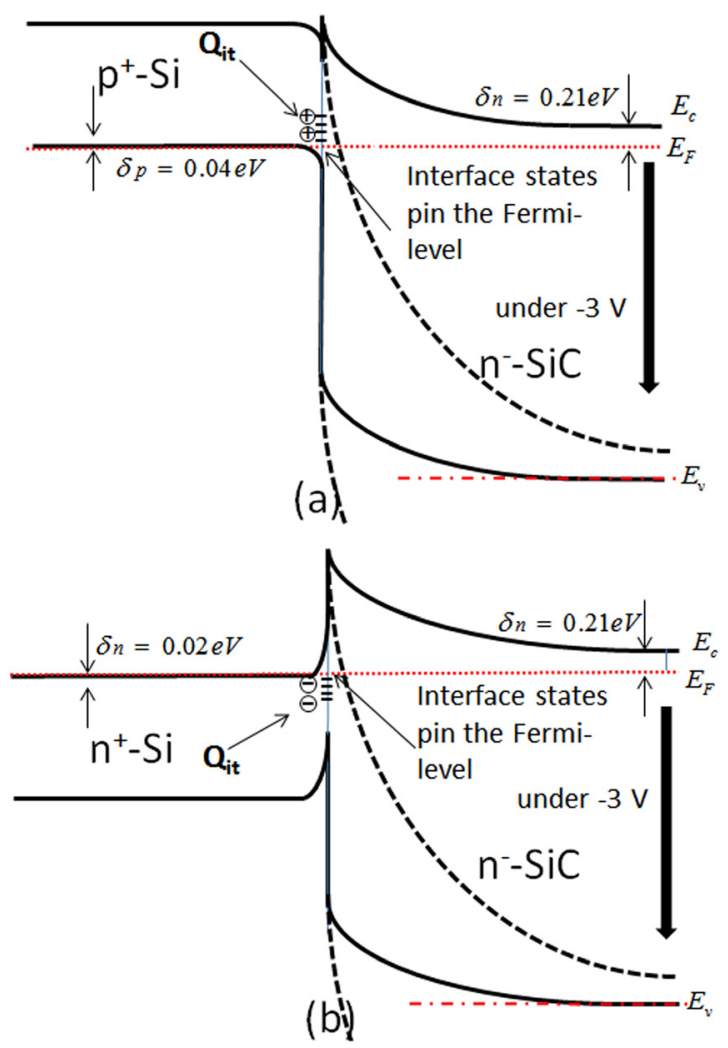

FIG. 4. Energy band diagrams for (a) $\mathrm{p}^{+}-\mathrm{Si} / \mathrm{n}^{-}-\mathrm{SiC}$ and (b) $\mathrm{n}^{+}-\mathrm{Si} / \mathrm{n}^{-}-\mathrm{SiC}$ junctions.

room temperature. The temperature dependence of the $I-V$ characteristics for $\mathrm{p}^{+}-\mathrm{Si} / \mathrm{n}^{-}-\mathrm{SiC}$ is alike to $\mathrm{n}^{+}-\mathrm{Si} / \mathrm{n}^{-}-\mathrm{SiC}$ junctions. We found that the flat band voltages of all $\mathrm{Si} / \mathrm{SiC}$ junctions were estimated to be $\sim 0.92 \mathrm{eV}$, which is attributed to Fermi-level pinning at the bonding interface. The influence of the interface state charges on the $C-V$ characteristics of $\mathrm{p}^{+}-\mathrm{Si} / \mathrm{n}^{-}-\mathrm{SiC}$ and $\mathrm{n}^{+}-\mathrm{Si} / \mathrm{n}^{-}-\mathrm{SiC}$ junctions was analyzed using the charge neutral level model. The modeled $C-V$ characteristics of $\mathrm{p}^{+}-\mathrm{Si} / \mathrm{n}^{-}-\mathrm{SiC}$ and $\mathrm{n}^{+}-\mathrm{Si} / \mathrm{n}^{-}-\mathrm{SiC}$ junctions are sensitive to the density of interface states and the conduction-band discontinuity. They are in agreement with the experimental results when the interface state density and the conduction-band discontinuity are $2.3 \times 10^{13} \mathrm{~cm}^{-2} \mathrm{eV}^{-1}$ and $0.3 \mathrm{eV}$, respectively. The estimated band profiles of junctions are consistent with the features of their $I-V$ characteristics.

This work was partly supported by "Creative research for clean energy generation using solar energy" project in Core Research for Evolutional Science and Technology (CREST) programs of the Japan Science and Technology Agency (JST).

${ }^{1}$ J. Scofield, H. Kosai, B. Jordan, S.-H. Ryu, S. Krishnaswami, F. Husna, and A. Agarwal, Proceedings of the ECSCRM 2006 Conference (Trans Tech Publications, 2007), Vol. 556.

${ }^{2}$ T. Sugii, T. Ito, Y. Furumura, M. Doki, F. Mieno, and M. Mada, J. Electrochem. Soc. 134, 2545 (1987).

${ }^{3}$ C. W. Liu and J. C. Sturm, J. Appl. Phys. 82, 4558 (1997).

${ }^{4}$ S. S. Sheng, M. G. Spencer, X. Tang, P. Zhou, K. Wongtchotigul, C. Taylor, and G. L. Harris, Mater. Sci. Eng. B 46, 147 (1997).

${ }^{5}$ K.-H. Wu, Y.-K. Fang, J.-H. Zhou, and J.-J. Ho, Jpn. J. Appl. Phys. 36, 5151 (1997).

${ }^{6}$ E. W. Kiewra and P. C. Wayner, J. Electrochem. Soc. 136, 740 (1989).

${ }^{7}$ A. Pèrez-Tomás, M. R. Jennings, M. Davis, J. A. Covington, P. A. Mawby, V. Shah, and T. Grasby, J. Appl. Phys. 102, 14505 (2007).

${ }^{8}$ A. N. Nazarov, Ya. N. Vovk, V. S. Lysenko, V. I. Turchanikov, V. A. Scryshevskii, and S. Ashok, J. Appl. Phys. 89, 4422 (2001).

${ }^{9}$ P. M. Gammon, A. Perez-Tomás, M. R. Jennings, A. M. Sanchez, C. Fisher, S. T. Thomas, B. T. Donnellan, and P. A. Mawby, Mater. Sci. Forum 740-742, 1006 (2013).

${ }^{10}$ J. Liang, S. Nishida, M. Arai, and N. Shigekawa, Appl. Phys. Lett. 104, 161604 (2014).

${ }^{11}$ H. Takagi, K. Kikuchi, R. Maeda, T. R. Chung, and T. Suga, Appl. Phys. Lett. 68, 2222 (1996).

${ }^{12}$ M. M. R. Howlader, T. Watanabe, and T. Suga, J. Vac. Sci. Technol. B 19, 2114 (2001).

${ }^{13}$ J. Liang, T. Miyazaki, M. Morimoto, S. Nishida, and N. Shigekawa, J. Appl. Phys. 114, 183703 (2013).

${ }^{14}$ F. A. Kish, D. A. Vanderwater, and M. J. Peanasky, Appl. Phys. Lett. 67, 2060 (1995).

${ }^{15}$ G. Lian, H. G. Xing, Y. Chang, and N. Fichtenbaum, Appl. Phys. Lett. 93, 112103 (2008).

${ }^{16}$ J. Kim, N. G. Toledo, S. Lal, J. Lu, T. E. Buehl, and U. K. Mishra, IEEE Electron Device Lett. 34, 42 (2013).

${ }^{17}$ P. M. Gammon, A. Perez-Tomás, M. R. Jennings, V. A. Shah, S. A. Boden, M. C. Davis, S. E. Burrows, N. R. Wilson, G. J. Roberts, J. A. Covington, and P. A. Mawby, J. Appl. Phys. 107, 124512 (2010).

${ }^{18}$ H. Hanafusa, A. Ohta, R. Ashihara, K. Maruyama, T. Mizuno, S. Hayashi, H. Murakami, and S. Higashi, Mater. Sci. Forum 778-780, 649 (2014).

${ }^{19}$ J. Robertson and B. Falabretti, J. Appl. Phys. 100, 014111 (2006).

${ }^{20}$ A. Pèrez-Tomás, M. R. Jennings, M. Davis, J. A. Covington, P. A. Mawby, V. Shah, and T. Grasby, Microelectron. J. 38, 1233 (2007).

${ }^{21}$ S. M. Sze, in Physics of Semiconductor Devices, 2nd ed. (Wiley, New York, 1981), pp. 144-202.

${ }^{22}$ M. Yoshimoto, R. Araki, T. Kurumi, and H. Kinoshita, ECS Trans. 50, 61 (2013). 